\title{
Accidental Opportunities? Women in Family Businesses Taking the Lead in a New Market Economy in Accra, Ghana
}

\author{
Doris A. Boateng
}

\begin{abstract}
Social workers have been working to empower women of diverse backgrounds across several practice settings. However, for women entrepreneurs in Ghana generally and those in family businesses specifically, some socio-cultural factors have persisted to hinder their abilities to promote and sustain their businesses. This paper describes the ways in which women in family businesses in Accra, Ghana have identified and leveraged opportunities presented by structural, cultural, socio-economic, and technological changes to ensure the success of their businesses. The study employed a qualitative research approach with purposive and snowball sampling used to identify and interview 15 women in family businesses. Findings indicate that women in family businesses in Accra, Ghana have creatively made use of the changing socio-cultural and economic landscape of the country to promote their businesses through three main trends which are significant in business growth: the advent and increasing use of social media, innovative business practices, and weakening patriarchy. We recommend that social workers apprise themselves of contexts which have unequal consequences for women and mobilize around these changes to help women entrepreneurs to take full advantage of the opportunities that are being offered in Ghana's emerging economy.
\end{abstract}

Keywords: Family business, women, opportunities, success, new market economy, Ghana

Family businesses have been on the increase in Ghana since the early 1980s. Defined as a business that is "owned, controlled and operated by members of a single family", family businesses "undergird and sustain" many economies throughout the world (Lerner \& Malach-Pines, 2011, p. 113). From pre-colonial times through the struggle for independence in Ghana, indigenous family businesses have been part of the country's economic make-up. Traditionally, family businesses in Ghana have been male dominated, but women are increasingly entering into the space either by setting up their own businesses or through inheritance. As a result of the Structural Adjustment Programs the nation embarked on in the 1970s and 1980s, dynamics for women's participation in the emerging market economy have changed considerably (Debrah, 2007; Dzisi, 2008).

Family businesses have engaged the attention of scholars due to their peculiarity of straddling both the domains of family and business (Payne, 2018). Studies have focused on the contributions of small family businesses to national development (Basco, 2015; Mason \& Harrison, 2017), succession issues in family businesses (Bozer et al., 2017; Thurman \& Nason, 2016), and have mainly taken a business and marketing outlook (Acquaah, 2016; Amankwaa et al., 2016; Cabrera \& Mauricio, 2017). There has been little attention from the field of social work or a social justice approach.

As part of its quest for social justice for all people, social work is concerned with the economic empowerment of women in lower and poor socio-economic contexts (Deka,

Doris A. Boateng, PhD, Senior Lecturer, Department of Social Work, University of Ghana, Legon, Accra, Ghana.

Copyright $(2021$ Authors, Vol. 21 No. 4 (Fall 2021), 1083-1099, DOI: 10.18060/24196

(cc) BY

This work is licensed under a Creative Commons Attribution 4.0 International License. 
2012; Lombard \& Twikirize, 2014). Social workers have been working to empower women of diverse backgrounds across several practice settings. However, for women entrepreneurs in Ghana generally and those in family businesses specifically, some socio-cultural factors have persisted to hinder their abilities to promote and sustain their businesses. In the larger socio-cultural framework of Ghana, women entrepreneurs face challenges such as lack of control over resources including land and labor, which in turn limit their eligibility for loans to expand their businesses. This accounts for the largely unsuccessful empowerment interventions and persistent gender inequalities in the country, as most of such empowerment initiatives fail to address existing socio-cultural barriers and inequalities (Ayentimi et al., 2020; Britwum et al., 2019).

When women are economically empowered, they are able to contribute equitably to the development of their communities, leading to sustained development of the entire economy of the country (Dandona, 2015). Seeking to proactively empower its women population will help Ghana attain the fifth and eighth United Nations (n.d.) Sustainable Development Goals (SDGs, Boateng, 2020). These goals seek to achieve gender equality and empower all women and girls and promote sustained, inclusive, and economic growth, full and productive employment, and decent work growth for all. Currently, several opportunities are emerging for women entrepreneurs generally, which those in family businesses are also leveraging to promote and sustain their businesses. Many opportunities have emerged on the Ghanaian economic landscape, which were hitherto, either not available or accessible to women. However, due to the ingenuity of women entrepreneurs in family businesses, they have created spaces for themselves to flourish, break barriers, and overcome challenges to their personal and business benefits.

Keeping sight of the global attention and the opportunities present for women in family businesses, this article highlights the ways in which women entrepreneurs in family businesses in Accra, Ghana have identified and leveraged the opportunities presented in a new market economy to ensure the success of their businesses. The findings presented will aid in providing recommendations for taking critical steps to ensure that such opportunities are harnessed while systemic, socio-cultural, and institutional barriers are removed for women to thrive like their counterparts in other developed economies.

\section{Family Businesses in A New Market Economy}

\section{Women in Small, Family Businesses}

Extant literature on women in family businesses reflects an ongoing debate among scholars belonging to two schools of thought (Bessière, 2014; Cesaroni \& Sentuti, 2014; Lerner et al., 2016). On one hand are those who believe that family businesses offer women opportunities that other businesses do not, while on the other are the scholars who have documented the many difficulties women endure in family businesses (Lerner \& MalachPines, 2011).

Faraudello and Songini (2018) reviewed the literature on women in family businesses and sought to develop a framework for discussing obstacles and opportunities for women in family businesses. They adopted Martinez Jimenez' (2009) classification of glass ceiling 
and women's invisibility, emotional leadership, succession and primogeniture - where women are hardly thought of as candidates but rather the firstborn male child is preferred to succeed to leadership - as the main factors that prevent women from reaching important positions in family businesses. Among these factors, glass ceilings and invisibility were considered the strongest obstacles.

Glass ceilings refer to the invisible and subtle barriers that prevent women from moving up in higher professional positions within organizations. In most instances, they apply to women and are used to keep them from advancing to higher levels based on their gender and not on their ability to handle higher level responsibilities (Faraudello \& Songini, 2018). In family businesses, glass ceilings become a major barrier to women's career advancement especially when there are male contenders for top positions.

In addition to glass ceilings, women's traditional gender roles as homemakers result in many of them being forced to devote more attention to the responsibilities connected to the family, while those connected to the business are addressed by a male counterpart within the family. These dynamics result in women's invisibility in family businesses. Women are also more likely to be ignored by non-family members who conduct business with the firm even if the woman is at the helm of affairs in the business (Martinez Jimenez, 2009). Working in a family business thus means that women must contend with all the problems associated with the family as well as those associated with the business. Danes et al. (2007) indicate that family businesses owned or managed by women earn less revenue than those owned by men, explaining that women and men tend to structure the interaction between work and family differently when they are running a family business. Also, many women in family businesses have had to contend with conflicts and doubts about their own identities, competencies and what they believe are the expectations other members of the family have of them.

Women who work in family businesses are more likely to have the freedom to find and achieve personal fulfilment coupled with greater opportunities for career advancement than women who work in organizations that are not owned by their families (Faraudello \& Songini, 2018). In an environment where women must work twice as hard before they can get the same recognition as men, working in a family business becomes the most fertile ground for career advancement and the attainment of success.

Until recently, female economic activities in the Ghanaian setting did not attract academic, scholarly, or political attention, making them relatively invisible, unrecorded, and disregarded as marginal (Langevang et al., 2015). However, there is now a growing recognition of the importance of women's economic roles as they provide goods and services in addition to employment, financial, and social support for their families, communities, and the country at large (Adom \& Asare-Yeboa, 2016). Women's historical contributions to the anti-colonial struggles have been recorded and recognized. For instance, Manuh (1991) reports that women traders and their associations organized and rallied to support Dr. Kwame Nkrumah in the lead up to the country's independence in 1957. To underscore the importance of the traders in the anti-colonial struggle and the success of Nkrumah's Convention People's Party (CPP), it was argued that "in the struggle for independence, one market woman...was worth any dozen Achimota graduates" 
(Manuh, 1991, p. 108). While women entrepreneurs have faced several challenges, they continue to be influential in Ghana's past, present, and future economy.

\section{Ghana as a New Market Economy}

Ghana became independent in 1957 and a republic in 1960. Although relatively poor, the country is fast becoming a middle-income country with its rich natural resources, mineral deposits, and high economic prospects for businesses (Debrah, 2002). However, like other African countries and similar to all emerging economies, Ghana has inadequate market supporting institutions and weak enforcement capacity of regulatory and legal institutions in Ghana (Acquaah, 2007; Adomako et al., 2020). This notwithstanding, the government of Ghana has exhibited commitment to ensuring the growth and success of the economy through various legislative and policy frameworks and reforms that seek to promote the welfare of its citizens.

New market economies are the "low-income, rapid-growth countries using economic liberalization as their primary engine of growth" (Hoskisson et al., 2000, p. 249). They are characterized as undergoing accelerated economic development with policies that favor economic liberalization and the adoption of a free-market system. As one of the 10 fastestgrowing economies in the world with high prospects for export-driven growth, Ghana is considered one of the emerging economies in Africa (Acquaah et al., 2008). Amoako-Adu and Eshun (2018) argue that economic growth in Africa will be enhanced by the expansion of small and medium-sized enterprises, most of which are sole proprietorships or family businesses. Such businesses have been identified to have a significant impact on the growth of national economies through the generation of employment, productivity, and innovation (Abor \& Biekpe, 2006). To date, there has been little focus on the role of women in contributing to this economic growth.

As a result of trade liberalization, the removal or reduction of barriers and restrictions on the exchange of commodities between nations, many manufacturing firms find it easier to obtain raw materials and inputs for production, while there has been an increase in the demand for goods from Western countries. In addition, "businesses have become more customer-friendly and competitor-focused, developing strategies to enhance product quality, relationships with customers and suppliers ...in order to reduce operating costs, increase demand, and deal with the heightened competition in the domestic market" (Acquaah, 2005, p. 209).

Beyond the institutional structures, there are also several socio-cultural factors that regulated the way businesses are operated in Ghana, and which also tended to influence the formal ways of doing business. However, in recent times, Ghanaian women entrepreneurs are setting trends in the entrepreneurial landscape by establishing businesses that were hitherto considered outside the domain of women (Dzisi, 2008). For instance, many women are now seen to be operating in construction or auto mechanic businesses, a feat that would have been considered foreign or even impossible about ten years ago.

Women entrepreneurs in Ghana are important parts of the economic fabric of the country. They create, manage, and ensure the sustainability of several innovations in the 
form of small and medium-scale enterprises (Amu, 2005). Women in Ghana are disproportionately concentrated in the informal sector in Ghana where most are generally self-employed. Their main activities in this sector are petty trading, food processing, and marketing food crops (Prah, 1996). Agyemang-Duah and colleagues (2006) indicate that about 60 percent of women entrepreneurs in Ghana are engaged in the informal sector in the areas of agriculture, manufacturing, and food processing. Many Ghanaian women tend to operate more traditional businesses with low potential for growth, such as food processing activities, handicrafts of various kinds, and dressmaking. Most microenterprises owned by women are operated by one person with over 70 percent of such businesses operating with capital ranging from less than $\$ 100$ to $\$ 1000$ (Amu, 2005).

Traditionally, due to the socio-cultural roles of women as homemakers, they are socialized from childhood to acquire entrepreneurial skills such as retail trading, food processing, and commerce (Dzisi, 2008), as these would allow them to remain close to home. In addition, informal sector activities such as trading and farming were, in the past, left for people with little or no education. In recent times, however, women entrepreneurs have carved a niche for themselves within the sector through enterprise development, capital mobilization, and social networking (Darkwah, 2007). Many women entrepreneurs can contribute equitably to the education and health of their children and also to household incomes (Amu, 2005). Contrary to the characteristics of traders in the past, Bowles (2013) notes that there are new emergent categories of entrepreneurs in Ghana,

[...] businesswomen who successfully navigate international networks in ways that rely on hyper-mobilized movement garnered through dual citizenship, affluent economic status stabilized by educational experiences abroad, and social ties fostered within and across nation-states. The results are incredible economic successes that are often unparalleled among their peers in Ghana. (p. 209)

Ghanaian women entrepreneurs thus "defy the general idea of the oppressed third world woman that is sometimes evident in the literature on women/gender and development" (Darkwah, 2002, p. 17).

There is a gap in the existing literature on the roles women have played in building and ensuring the sustenance of successful family businesses in Ghana, despite the sociocultural challenges that abound in Ghanaian society. Though the number of women involved in the ownership, management, and direction of family businesses is increasing over time, their efforts are too often "invisible" and go unrewarded. Thus, this study sought to answer the following research questions:

i. From the perspectives of women in family businesses in Ghana, in what ways have women's roles in family businesses changed over the last five years?

ii. What do women in family businesses in Ghana consider as opportunities for recognition and success?

\section{Method}

The study employed a qualitative research design in its approach. Fifteen women in family businesses were recruited to participate in the study to discuss the ways in which 
their roles have changed over the past five years and highlight how these changes have impacted their businesses. Women in family businesses were the population of choice due to the patriarchal nature of the Ghanaian society that negatively reflect on issues of succession in family businesses, irrespective of primogeniture, qualification, or ability to perform for women. The 15 respondents were recruited mainly through purposive and snowball sampling techniques. Initially, 3 participants were purposively selected based on the researcher's familiarity with their businesses. After interviewing each participant, they were asked to recommend other women in family businesses for participation in the study. It was necessary to rely on snowball sampling techniques due to the difficulty in identifying and separating women in family businesses from women entrepreneurs. Information was solicited mainly through in-depth interviews (IDIs). Data were collected between October 2017 and March 2018. Ethical approval was sought from the University of Ghana College of Humanities Institutional Review Board (IRB) before proceeding to collect data.

Due to the exploratory nature of this study, in-depth interviews served as a powerful way of helping participants to make explicit things that have hitherto been implicit - to articulate their tacit perceptions, feelings, and understanding. A semi-structured interview guide was developed with open-ended questions which allowed respondents to tell their stories from their own perspectives. With permission from the participants, all interviews were audio-recorded for later transcription. Interviews were conducted in English, and each interview lasted an average of 45 minutes. All the interviews were one-on-one sessions except for one, in which a mother was interviewed with her daughter at the same time. Although this was not planned, it allowed for differences in views and opinions that reflected the changing patterns in the Ghanaian culture to be evident.

The recorded data were transcribed verbatim from audio to text. Data were analyzed using Clarke and Braun's (2014) six steps of thematic analysis. These steps are becoming familiar with the data, generating codes, categorizing generated codes into themes, reviewing and identifying themes, defining and naming the themes, and preparing a report based on the themes. Themes and sub-themes were then subjected to member checking and peer vetting to ensure trustworthiness and credibility of findings. The identified broad themes with its sub-themes were used to characterize the study's key findings. In order to safeguard the identities of the participants, pseudonyms are used in the reporting of their views. The author conducted all the interviews and analyses independently.

\section{Profile of Study Participants}

The fifteen women who participated in the study were all entrepreneurs who were engaged in family businesses in Accra, Ghana. They ranged in age from 26 to 63 years old. The ages of the participants are indicative of the fact that women are encouraged to be entrepreneurial from a very young age through to their late adulthood in order to be able to provide for themselves and their families (Britwum et al., 2006). In terms of education, three of the participants had post-graduate education, five had bachelor's degrees, two each had Middle School Leavers' Certificates, National Vocational Training Institute Certificates, secondary school (high school) certificates, while one had a certificate in Nursing and Midwifery. Eight of the participants were first generation women in family 
businesses who had either started the businesses by themselves or with their husbands and six were second generation with one being a third-generation woman in the business. This is consistent with the African business landscape in which few family businesses survive beyond the third-generation (Amankwaa et al., 2016).

To be able to solicit views from as many perspectives as possible, the women were selected from varied sectors of the economy. Five of the women were engaged in the trading of general household consumables and beauty products, three were operating basic schools, two were in the catering industry, while one each was engaged in health care provision, construction, freight forwarding, sculpture and export, and fashion design and export. The distribution of women across the different sectors also indicates the concentration of women in the provision of services that reflect the socio-cultural roles of women in Ghanaian society. Table 1 provides a synopsis of the profile of the study participants.

Table 1. Socio-Demographic Characteristics of Participants $(n=15)$

\begin{tabular}{|c|c|c|c|c|}
\hline $\begin{array}{l}\text { Participants' } \\
\text { pseudonym }\end{array}$ & $\begin{array}{c}\text { Age } \\
\text { (years) }\end{array}$ & Educational Level & $\begin{array}{l}\text { Marital } \\
\text { status }\end{array}$ & Business \\
\hline Miss Abby & 32 & Master's Degree & Single & Sculpting \& export \\
\hline Miss Ash & 42 & $\begin{array}{l}\text { Middle School Leavers' } \\
\text { Certificate }\end{array}$ & Married & Trade in household products \\
\hline Miss Babs & 26 & $\begin{array}{l}\text { National Vocational Training } \\
\text { Institute Certificate II }\end{array}$ & Married & Catering \\
\hline Miss Bea & 40 & Bachelor's Degree & Married & Freight forwarding \\
\hline Miss Cee & 34 & Postgraduate Diploma & Married & School proprietor \\
\hline Miss Dede & 33 & Postgraduate Diploma & Married & School proprietor \\
\hline Miss Ed & 58 & $\begin{array}{l}\text { National Vocational Training } \\
\text { Institute Certificate I }\end{array}$ & Married & Catering \\
\hline Miss Em & 38 & Bachelor's Degree & Married & Construction \\
\hline Miss Gee & 35 & Bachelor's Degree & Married & $\begin{array}{l}\text { Wholesale \& retail trade in } \\
\text { hair \& beauty products }\end{array}$ \\
\hline Miss Kay & 35 & Bachelor's Degree & Single & Fashion design \& export \\
\hline Miss Lou & 42 & Secondary School Certificate & Married & $\begin{array}{l}\text { Wholesale trade in general } \\
\text { consumables }\end{array}$ \\
\hline Miss Naa & 36 & Secondary School Certificate & Single & $\begin{array}{l}\text { Retail trade in household } \\
\text { products }\end{array}$ \\
\hline Miss Nora & 65 & $\begin{array}{l}\text { Middle School Leavers' } \\
\text { Certificate }\end{array}$ & Widowed & $\begin{array}{l}\text { Trade in greeting cards \& } \\
\text { other products }\end{array}$ \\
\hline Miss Pee & 34 & Bachelor's Degree & Married & School proprietor \\
\hline Miss Shay & 66 & $\begin{array}{l}\text { Diploma in Nursing \& } \\
\text { Midwifery }\end{array}$ & Married & Healthcare provider \\
\hline
\end{tabular}

\section{Findings}

The findings of the study indicate that women in family businesses in Accra, Ghana have creatively identified and made use of the changing socio-cultural and economic 
landscape of the country to promote their businesses. This paper highlights three main trends that have been significant in business growth and success and, in turn led to economic empowerment for women in family businesses in Accra, Ghana. These trends are termed broadly as accidental opportunities because they were not deliberately planned but were still identified and exploited in ways that are increasingly beneficial to women and their businesses.

\section{Advent and Increasing Use of Social Media}

In recent years, smart phones and their accompanying social media usage have provided avenues for many women entrepreneurs to reach, advertise, and conduct business with people all over the country and all over the world. The study participants indicated that, through social media portals like Facebook, Twitter, WhatsApp, and Instagram, they are able to advertise their products to clients, share information, and generally conduct business in ways that they could not have conceived of in the past. However, the use of social media was more popular and useful for those women who traded in goods than those who provided services:

Facebook has been instrumental in the way I conduct business. At first, people had to come into the shop to see my products, but now, all I have to do is post pictures on Facebook, and people are able to see them and place orders from all over the world. It is great! (Miss Kay, fashion designer).

I use Instagram, Facebook, and WhatsApp. I take pictures and post them online and people are able to call or send messages to order. It is that simple. For customers in Ghana, they pay when I deliver but for those abroad, they have to pay before shipping. Oh yes, social media has been great, I am able to transact business all over the world. Once people know that you will deliver, they are willing to do business with you. Who would have thought that I will sit here and be able to ship products to France, Germany and even Australia? (Miss Abby, sculptor \& exporter).

For the women whose businesses entailed the provision of services, social media is useful since it allows people to review their businesses and recommend them to others. They strive to provide top-notch services to clients so that they will receive good ratings and get referrals. As some noted:

These days, if you offend a client, they can use social media to destroy your business with the click of a button, so I make sure to train my staff to be most professional to everyone. In that same breath, if a client is truly satisfied, they use social media to help promote the business (Miss Dede, school proprietor).

I often get clients who only come because they read something positive about us on one social media platform. I have a page on Facebook where I ask clients to share their experiences, and I believe that my business has improved greatly due to that (Miss Shay, healthcare provider). 


\section{Innovative Business Practices}

Many women entrepreneurs in Ghana are applying different innovations in conducting and promoting their businesses. Among them are the conversion of cars to shops, organizing street mall events, identifying the needs of people, and providing targeted solutions. It is not an uncommon feature to see many women entrepreneurs carrying their products in their cars to vantage business locations to advertise and sell them. The participants indicated that these innovations on their part have proven to significantly contribute to the success of their businesses. Even for participants who provided services, these innovations have been useful:

When I took over the business, I realized that sales at the shop were low, so I would put some of my products in a car and drive from office to office. I could make more sales that way than sitting at the shop and expecting people to show up (Miss Naa, trader).

You see, it could be that people need items but do not have the time to go shopping, or that you are located too far from where they are, but if you make the effort to take the things to them, they will buy. I go to the banks and other offices with different designs and people are more than happy to just buy them (Miss Kay, fashion designer \& exporter).

We package sauces and soups for career women all the time. If they call and tell us what they want, we prepare and package them so they either pick them up or we deliver them in ice chests so that when they get home, they refrigerate them. Women are busy these days and are grateful that we are here to offer them such services. Recently a customer called to order food that would last a whole month (Miss Babs, caterer).

Other entrepreneurs organize and participate in street malls. This is a recent phenomenon where a whole stretch of road is blocked off (with permission of city authorities) and stands are mounted for a day to advertise and sell products. The entrepreneurs who participated in these events appreciate the ways they contribute to the success of their businesses:

These street malls are one-day events, but you make the most sales. You know how people of a certain caliber patronize these events, and such people like to shop so it is very good, but then, many more people tell me if not for such events they would not even know of my business (Miss Abby, sculptor \& exporter).

One would think that as a construction company, we would not benefit from the street malls, but we really do. When we go and meet people, tell them what services we can provide for them and even the kind of financial arrangements we can go into in the construction of their homes, we often get follow up jobs. I think those events are great and wish they could be organized more frequently (Miss Em, construction worker). 


\section{Weakening Patriarchy}

The Ghanaian society is experiencing fast-paced development in which patriarchy is increasingly weakening. Due to several campaigns and efforts by government to promote gender equality, many men have become more sensitive to the needs of women and have become allies in the promotion of women's rights. The study participants have identified this as great leverage upon which to launch and promote businesses in the country to inure to their benefit:

If I should say so myself, the business has greatly improved since I took over from my mother. When I compare myself to my mother, she could not travel to China and Hong Kong to buy the goods because she could not leave us at home, so the business was not doing well. But since I took over, me, I travel all over-China, Hong Kong, Thailand, and Dubai. Nobody ever gives me grief that a woman's place is the home or the kitchen (Miss Naa, Trader in general consumables).

I think the way the system [sic] has changed in Ghana is very good. These days when you are doing business, nobody looks at you like you are doing something wrong. At first, people didn't think construction could be women's business, but now, I wear my hard hat and boots and go to sites without any problems (Miss Em, construction worker).

In the mother and daughter interview, some of these changes were also evident:

Although my husband invested in the business, he has not been a great support. He insists that catering is a business for women, so he does not even encourage my son to be part of the business, but he had no problem when I started grooming her [the daughter] to take over the business. Now, she is married, and her husband helps out here all the time. He keeps our books, helps with purchases or deliveries when we need extra hands, and just keeps an interest in the business (Miss Ed, caterer).

Besides the changing perspectives in the broader social system, in private homes the weakening patriarchy is also evident in the way men do not have expectation of their wives as being solely responsible for cooking, cleaning, and taking care of children.

Most of the time, I close from the shop late, so it is my husband who picks the children from school, does homework, feed, and bathe them before I get home. He does not have any complaints whatsoever about doing that and this gives me the peace of mind to also focus on my business (Miss Kay, fashion designer \& exporter).

I like how my husband does not insist that I cook. Usually, I order food and we eat, or he would cook. Growing up, I never saw my father cook and I am sure in times past, I would have been considered a bad wife, but not now (Miss Bea, freight forwarder). 


\section{Discussion}

This paper sought to answer two research questions regarding women in family businesses in Ghana from their own perspectives: 1) in what ways have women's roles in family businesses changed over the last five years and 2) what are their opportunities for recognition and success? From the findings of this study, it is evident that some Ghanaian women in family businesses in Accra, Ghana are able to identify and leverage opportunities in their communities to promote and sustain their businesses, which ultimately lead to their economic empowerment. Empowered women are able to make decisions that benefit them and their families, and they contribute positively to the development of their communities. Since such women also seek the well-being of others, they in turn ensure the empowerment of other women and children associated with them. It is, therefore, instructive that at the micro level, women who participated in this study have identified and utilized the opportunities in their environment to promote their businesses. While women in family businesses are doing their bit to promote social justice, they need to be further supported to ensure that opportunities be institutionalized and spread to cover all women in the country through advocacy, brokering, facilitation, and education.

At the macro level, there appear to be more opportunities for women in both the formal and informal sectors due to changes in gender roles and weakening patriarchy in Ghanaian society. Through social change, exposure, and education, the burden of keeping the home and caring for children is no longer the sole responsibility of women. More men are now taking up domestic responsibilities in the home, giving women more time to pursue their professional endeavors. There also appears to be cracks in glass ceilings in many organizations and family businesses, and so women who push hard enough are able to pass through the cracks and rise to the top. Although many women have to work twice as hard to get the same kind of recognition and promotion as men, the fact that some have identified these cracks and are taking advantage of the opportunities presented is worthy of recognition.

In addition, the new market economy with its accompanying policy reforms has resulted in women having more agency. Unlike the past, women are now able to procure and own assets. This means that women are also able to start their own businesses, use their assets to secure loans from banks to expand and even contract with third parties to do business. These changes and the opportunities they come with must be consciously created and presented to women in other sectors of the economy to ensure that they can also succeed in their fields of endeavor.

This is where the expertise of social workers can prove to be most useful. Social workers could work with the women themselves, civil society, and government to formulate policies that would create the opportunity for women entrepreneurs in both the formal and informal sectors in order to sustain their businesses. In this regard, social workers in Accra, Ghana have a duty to work with women entrepreneurs so that they are able to galvanize around the changing economic landscape for the benefit of themselves and their families. 
In an emerging economy like Ghana, social workers can provide women in family business with technical assistance and information on how to navigate the terrain and make use of their networks to ensure the success of their businesses. They can also work in concert with the women themselves to advocate for better working conditions with an emphasis on increasing support for women entrepreneurs. As Deka (2012) notes, social workers have been instrumental in expediting approaches for change which have proven useful in countering the marginalizing effects of poverty in several jurisdictions. Again, social workers, having gained a clear understanding of the dynamics of rural settings as it relates to entrepreneurship development, can liaise with other female business owners to provide training to meet the specific needs of rural women.

Many scholars whose research has focused on women entrepreneurs in Ghana have either centered on their challenges (Dzisi, 2008), entrepreneurial choices (Acheampong, 2017), the economic landscape or factors that affect the success of female entrepreneurs (Cabrera \& Mauricio, 2017). Presently, the nexus between social work practice models and economic empowerment of women in emerging economies is very much untapped (Havig \& Byers, 2019). There is need to identify the physical, social, economic, and cultural barriers that continue to disempower women entrepreneurs in Ghana and strive for their removal. The United Nations (n.d.) Sustainable Development Goals have provided social workers with new opportunities to protect and promote social justice, human rights, and sustainable development. The SDGs - goals 1, 2, 5 and 16 among others - provide the framework for social workers to challenge the status quo, advocate for the rights of populations such as women entrepreneurs who are pioneers with a unique set of strengths, to be respected and to pursue the dignity and worth of all individuals in the Ghanaian society.

\section{Social Work Practice Implications}

The International Federation of Social Workers (IFSW), the International Association for Schools of Social Work (IASSW), and the International Council for Social Welfare affirm that past and present political, economic, cultural, and social orders, shaped in specific contexts, have unequal consequences for global, national, and local communities and can have negative consequences on individuals (Jones \& Truell, 2012). It is imperative, therefore, for social workers to be more aware of these past and present conditions and their impacts on specific groups of people, so that interventions for and/or with such groups will be tailored to reflect these unequal consequences.

For women entrepreneurs in Ghana, there continue to be systemic and socio-cultural barriers that hinder them from expanding and competitively running their businesses like their counterparts in other developed countries. Despite the socio-economic and cultural barriers faced by women in Ghana, some are still finding ways to thrive to assist their families and contribute to economic development. Hence, policy makers should recognize their efforts and eradicate systemic barriers to allow women full access to enable their growth and contribution to economic development in Ghana. Social workers can also play their part in educating and training women who are not yet aware of these emerging opportunities or not yet using these emerging opportunities to their advantage. Social 
workers can also advocate for the eradication of policies that create and perpetuate systemic barriers for women in Ghana.

There have been calls for African governments to deliberately target the informal sector for the creation of gainful employment opportunities to spur development (Debrah, 2007). Social workers in Ghana should work with the government to identify the informal sector as an area that possesses great potential for women, young and old, educated and otherwise, to exploit for greater economic empowerment. There is potential for future research to be conducted in this field, first to identify the specific socio-cultural differences that exist between women entrepreneurs in Ghana and their counterparts in more developed countries and how these differences can be either harnessed or mitigated.

\section{Conclusion}

The Ghanaian economic, social, cultural, and political landscape is rapidly changing along with the expectations of women, men, and children. Many women entrepreneurs in family businesses are identifying these changes and using them for the benefit of themselves, their businesses, and their families. Since social workers in Ghana are committed to the promotion of the rights of individuals and communities, the time has come to mobilize around these changes and help more women to fully take advantage of the opportunities that are being offered in this emerging economy.

\section{References}

Abor, J., \& Biekpe, N. (2006). Small business reliance on bank financing in Ghana.

Emerging Markets Finance and Trade, 43(4), 93-102.

https://doi.org/10.2753/REE1540-496X430405

Acheampong, G. (2017). Beyond the EJ model: Entrepreneurial orientation and industry choice of Ghanaian entrepreneurs. Journal of Global Entrepreneurship Research, 7(1), 28. https://doi.org/10.1186/s40497-017-0086-y

Acquaah, M. (2005). Enterprise ownership, market competition and manufacturing priorities in a sub-Saharan African emerging economy: Evidence from Ghana. Journal of Management \& Governance, 9(3-4), 205-235. https://doi.org/10.1007/s10997-005-7418-y

Acquaah, M. (2007). Managerial social capital, strategic orientation, and organizational performance in an emerging economy. Strategic Management Journal, 28(12), 12351255. https://doi.org/10.1002/smj.632

Acquaah, M. (2016). Family businesses in Sub-Saharan Africa: Behavioural and strategic perspectives. Palgrave Macmillan.

Acquaah, M., Adjei, M. C., \& Mensa-Bonsu, I. F. (2008). Competitive strategy, environmental characteristics and performance in African emerging economies: Lessons from firms in Ghana. Journal of African Business, 9(1), 93-120. https://doi.org/10.1080/15228910802052732 
Adom, K., \& Asare-Yeboa, I. T. (2016). An evaluation of human capital theory and female entrepreneurship in sub-Sahara Africa. International Journal of Gender and Entrepreneurship, 8(4), 402-423. https://doi.org/10.1108/IJGE-12-2015-0048

Adomako, S., Amankwah-Amoah, J., Debrah, Y. A., Khan, Z., Chu, I., \& Robinson, C. (2020). Institutional voids, economic adversity and inter-firm cooperation in an emerging market: The mediating role of government R\&D support. British Journal of Management, 32, 40-58. https://doi.org/10.1111/1467-8551.12443

Agyeman-Duah, K., Manu A. O., Cobbinah, E., Mintah, S., \& Anyinful, E. (2006). Women and men in Ghana: A statistical compendium. The Government Statistician. https://www2.statsghana.gov.gh/docfiles/Gender $\% 20$ Statistics $\% 20 \% 20$ (Women $\% 20$ $\& \% 20 \mathrm{Men}) . \mathrm{pdf}$

Amankwaa, R., Hodibert, V. A., \& Kwabiah, A. (2016). Towards defining family business in Ghana: The perspective of SME owners in Takoradi Metropolis, Ghana. ADRRI Journal (Multidisciplinary), 25(10), 49-62. https://journals.adrri.org/index.php/adrrij/article/view/300/286

Amoako-Adu, B., \& Eshun, J. P. (2018). SME financing in Africa: Collateral lending vs cash flow lending. International Journal of Economics and Finance, 10(6), 151-159. https://doi.org/10.5539/ijef.v10n6p151

Amu, N. J. (2005). The role of women in Ghana's economy. Friedrich Ebert Stiftung. http://library.fes.de/pdf-files//bueros/ghana/02990.pdf

Ayentimi, D. T., Abadi, H. A., Adjei, B., \& Burgess, J. (2020). Gender equity and inclusion in Ghana; good intentions, uneven progress. Labour \& Industry, 30(1), 6684. https://doi.org/10.1080/10301763.2019.1697486

Basco, R. (2015). Family business and regional development-A theoretical model of regional familiness. Journal of Family Business Strategy, 6(4), 259-271. https://doi.org/10.1016/j.jfbs.2015.04.004

Bessière, C. (2014). Female and male domestic partners in wine-grape farms (Cognac, France): Conjugal asymmetry and gender discrimination in family businesses. History of the Family, 19(3), 341-357. https://doi.org/10.1080/1081602x.2014.934880

Boateng, D. A (2020). Pathways for the economic empowerment of female entrepreneurs in emerging economies: Implications for social work. International Social Work, 64(2), 216-232. https://doi.org/10.1177/0020872819896846

Bowles, L. R. (2013). Transnational mobility, social capital, and cosmopolitan women traders in Ghana. African and Black Diaspora: An International Journal, 6(2), 208217. https://doi.org/10.1080/17528631.2013.793138

Bozer, G., Levin, L., \& Santora, J. C. (2017). Succession in family business: Multisource perspectives. Journal of Small Business and Enterprise Development, 24(4), 
753-774. https://www.emerald.com/insight/content/doi/10.1108/JSBED-10-2016$\underline{0163 / \mathrm{full} / \mathrm{html}}$

Britwum, A. O., Akorsu, A. D., \& Baidoo, L. (2019). Women's empowerment for sustainable rural livelihoods: Voices from selected communities in Ghana. https://www.uni-kassel.de/upress/online/OpenAccess/978-3-7376-06301.OpenAccess.pdf

Britwum, A. O., Ghartey, N. K. T., \& Agbesinyale, P. K. (2006). Organizing labour in the informal sector: The conditions of rural agriculture in Ghana. Ghana Universities Press. https://www.ajol.info/index.php/gjds/article/view/48930

Cabrera, E. M., \& Mauricio, D. (2017). Factors affecting the success of women's entrepreneurship: A review of literature. International Journal of Gender and Entrepreneurship, 9(1), 31-65. https://doi.org/10.1108/IJGE-01-2016-0001

Cesaroni, F. M. \& Sentuti, A. (2014). Women and family businesses. When women are left only minor roles. History of the Family, 19(3), 358-379. https://doi.org/10.1080/1081602x.2014.929019

Clarke, V., \& Braun, V. (2014). Thematic analysis. In Encyclopedia of critical psychology (pp. 1947-1952). Springer. https://doi.org/10.1007/978-1-4614-558373311

Dandona, A. (2015). Empowerment of women: A conceptual framework. International Journal of Indian Psychology, 2(3), 35-45. https://doi.org/10.25215/0203.044

Danes, S. M., Stafford, K., \& Loy, J. T.-C. (2007). Family business performance: The effects of gender and management. Journal of Business Research, 60(10), 10581069. https://doi.org/10.1016/j.jbusres.2006.12.013

Darkwah, A. K. (2002). Going global: Ghanaian female transnational traders in an era of globalization (Doctoral dissertation, University of Wisconsin-Madison). ProQuest Dissertations Publishing. https://search.proquest.com/openview/7a61e3d7177cd25fa718c50624d79dd4/1?pqorigsite $=$ gscholar $\& \mathrm{cbl}=18750 \&$ diss $=y$

Darkwah, A. K. (2007). Making hay while the sun shines: Ghanaian female traders and their insertion into the global economy. In N. Gunewardena \& A. Kingsolver (Eds), The gender of globalisation: Women navigating cultural and economic marginality (pp. 61-83). James Currey.

Debrah, Y. A. (2002). Doing business in Ghana. Thunderbird International Business Review, 44(4), 495-513. https://doi.org/https://doi.org/10.1002/tie.10028

Debrah, Y. A. (2007). Promoting the informal sector as a source of gainful employment in developing countries: Insights from Ghana. International Journal of Human Resource Management, 18(6), 1063-1084. https://doi.org/10.1080/09585190701321716 
Deka, A. (2012). Local and global poverty: Insights using a rights-based approach. Advances in Social Work, 3(2), 471-483. https://doi.org/https://doi.org/10.18060/1967

Dzisi, S. (2008). Entrepreneurial activities of indigenous African women: A case of Ghana. Journal of Enterprising Communities: People and Places in the Global Economy, 2(3), 254-264. https://doi.org/10.1108/17506200810897231

Faraudello, A., \& Songini, L. (2018). Women's role in family business: Evolution and evidences from a European case study. Journal of Modern Accounting and Auditing, 14(2), 70-89. https://doi.org/10.17265/1548-6583/2018.02.003

Havig, K., \& Byers, L. (2019). Truth, reconciliation, and social work: A critical pathway to social justice and anti-oppressive practice. Journal of Social Work Values and Ethics, 16(2), 70-80. https://jswve.org/download/fall_2019 volume 16 no. 2/articles/70-Truthreconciliation-social-work-16-2-Fall-2019-JSWVE.pdf

Hoskisson, R. E., Eden, L., Lau, C. M., \& Wright, M. (2000). Strategy in emerging economies. Academy of Management Journal, 43(3), 249-267. https://doi.org/10.2307/1556394

Jones, D. N., \& Truell, R. (2012). The global agenda for social work and social development: A place to link together and be effective in a globalized world. International Social Work, 55(4), 454-472. https://doi.org/10.1177/0020872812440587

Langevang, T., Gough, K. V., Yankson, P. W., Owusu, G., \& Osei, R. (2015). Bounded entrepreneurial vitality: The mixed embeddedness of female entrepreneurship.

Economic Geography, 91(4), 449-473. https://doi.org/https://doi.org/10.1111/ecge.12092

Lerner, J., Ledbetter, J., Speen, A., Leamon, A., \& Allen, C. (2016). Private equity in emerging markets: Yesterday, today, and tomorrow. Journal of Private Equity, 19(3), 8-20. https://doi.org/10.2469/dig.v46.n12.3

Lerner, M., \& Malach-Pines, A. (2011). Gender and culture in family business: A tennation study. International Journal of Cross Cultural Management, 11(2), 113-131. https://doi.org/10.1177/1470595811399190

Lombard, A., \& Twikirize, J. M. (2014). Promoting social and economic equality: Social workers' contribution to social justice and social development in South Africa and Uganda. International Social Work, 57(4), 313-325. https://doi.org/10.1177/0020872814525813

Manuh, T. (1991, November 23-26). The status of research on women in Ghana [Paper \#61]. A paper presented at the 34th Annual Conference of the African Studies Association (ASA), St. Louis, MO. Emory University. https://www.africabib.org/rec.php?RID=W00084056 
Martinez Jimenez, R. (2009). Research on women in family firms: Current status and future directions. Family Business Review, 22(1), 53-64.

https://doi.org/10.1177/0894486508328813

Mason, C., \& Harrison, R. (2017). Informal venture capital and the financing of emerging growth businesses. In D. L. Sexton \& H. Landström (Eds.), Blackwell handbook of entrepreneurship (pp. 221-239). Blackwell Publishers Ltd. https://doi.org/10.1002/9781405164214.ch11

Payne, G. T. (2018). Reflections on family business research: Considering domains and theory. Sage.

Prah, M. (1996). Women's studies in Ghana. Women's Studies Quarterly, 24(1/2), 412422. https://www.jstor.org/stable/40004542

Thurman, P. W., \& Nason, R. S. (2016). Father-daughter succession in family business: A cross-cultural perspective. CRC Press.

United Nations. (n.d.). Sustainable development goals. https://sdgs.un.org/goals

Author note: Address correspondence to Doris A. Boateng, Department of Social Work.

P. O. Box LG 419, University of Ghana, Legon. Email: dboateng@ug.edu.gh 